NBER WORKING PAPER SERIES

\title{
GROWTH ACCELERATIONS
}

\author{
Ricardo Hausmann \\ Lant Pritchett \\ Dani Rodrik
}

Working Paper 10566

http://www.nber.org/papers/w10566

\section{NATIONAL BUREAU OF ECONOMIC RESEARCH 1050 Massachusetts Avenue Cambridge, MA 02138 \\ June 2004}

We thank Stanley Watt for excellent research assistance, and the Weatherhead Center for International Affairs for financial support. Dani Rodrik thanks for the Carnegie Scholars program for financial assistance. The views expressed herein are those of the author(s) and not necessarily those of the National Bureau of Economic Research.

(C2004 by Ricardo Hausmann, Lant Pritchett, and Dani Rodrik. All rights reserved. Short sections of text, not to exceed two paragraphs, may be quoted without explicit permission provided that full credit, including (C) notice, is given to the source. 
Growth Accelerations

Ricardo Hausmann, Lant Pritchett, and Dani Rodrik

NBER Working Paper No. 10566

June 2004

JEL No. O0, O5

\section{$\underline{\text { ABSTRACT }}$}

Unlike most cross-country growth analyses, we focus on turning points in growth performance. We look for instances of rapid acceleration in economic growth that are sustained for at least eight years and identify more than 80 such episodes since the 1950s. Growth accelerations tend to be correlated with increases in investment and trade, and with real exchange rate depreciations. Political-regime changes are statistically significant predictors of growth accelerations. External shocks tend to produce growth accelerations that eventually fizzle out, while economic reform is a statistically significant predictor of growth accelerations that are sustained. However, growth accelerations tend to be highly upredictable: the vast majority of growth accelerations are unrelated to standard determinants and most instances of economic reform do not produce growth accelerations.

Ricardo Hausmann

John F. Kennedy School of Government

Harvard University

79 JFK Street

Cambridge, MA 02138

ricardo_hausmann@harvard.edu

Lant Pritchett

John F. Kennedy School of Government

Harvard University

79 JFK Street

Cambridge, MA 02138

lant_pritchett@harvard.edu

Dani Rodrik

John F. Kennedy School of Government

Harvard University

79 JFK Street

Cambridge, MA 02138

and NBER

dani@rodrik@harvard.edu 


\section{Introduction}

Accelerating the process of economic growth in a sustained manner is just about the most important policy issue in economics. Economists have long used a variety of econometric approaches to shed light on why some countries grow faster than others. Early work focused on cross-section econometrics, with growth rates over two or three regressed on country characteristics and policies (Barro 1991, Barro and Sala-i-Martin 1992). More recent work has focused on levels-regressions with incomes (rather than growth) as the dependent variable (Hall and Jones 1999, Acemoglu, Johnson, and Robinson 2001) and on panel econometrics which organizes the country-level data in averages over five-year or other intervals (Islam 1995, Caselli, Esquivel, and LeFort 1996). The policy prescriptions coming out of this work have tended to be summarized under three broad principles: openness, sound money, and property rights. There are by now a number of good surveys and evaluations of this empirical literature, including especially Temple (1999), Durlauf (2003), and Easterly (2003).

A curious aspect of this literature is that it does not focus on what is perhaps the most telling source of variation in the underlying data. As Easterly et al. (1993) first pointed out and many others have reconfirmed since, growth performance tends to be highly unstable. Very few countries have experienced consistently high growth rates over periods of several decades. The more typical pattern is that countries experience phases of growth, stagnation, or decline of varying length (Pritchett 2000). And standard growth theory, whether of the neoclassical or the endogenous variant, suggests that our best bet for uncovering the relation between growth and its fundamentals is to look for instances where trend growth experiences a clear shift.

This point can be seen from Figure 1.1, which shows the implications of a (permanent) improvement in "growth fundamentals" at time $T$ in the two classes of models mentioned above. In the neoclassical growth model, growth accelerates at $T$, but eventually converges back to the growth rate prevailing prior to $T$ (unless the fundamental in question is exogenous technological progress). In endogenous growth models, growth accelerates permanently at time $T$. But in both cases, if we are interested in identifying the relevant growth fundamentals, our best strategy would be to look for changes that happen in the economy at or before time $T$. In other words, we can get significant mileage by identifying the turning points in growth experience and asking for what determines these transitions. If instead we lumped together data on growth without paying attention to these turning points, we would be averaging out the most interesting variation in the data.

By organizing the data around the turning points in growth experience, we also come significantly closer to answering the questions that most preoccupy policy makers. Policy makers want to know: how likely is it that an economy undergoes a significant acceleration of its rate of growth for a sustained period of time? What policies or other correlates seem to be associated with such transitions? What can be said about the causes of such transitions? Are they in line with current views as to the relative importance of economic reforms and institutions? Policy makers may be rightly concerned about the possibility that while the standard cross-country regressions tend to get the determinants 
right over a sufficiently long time period, they are very poor predictors of turning points of growth.

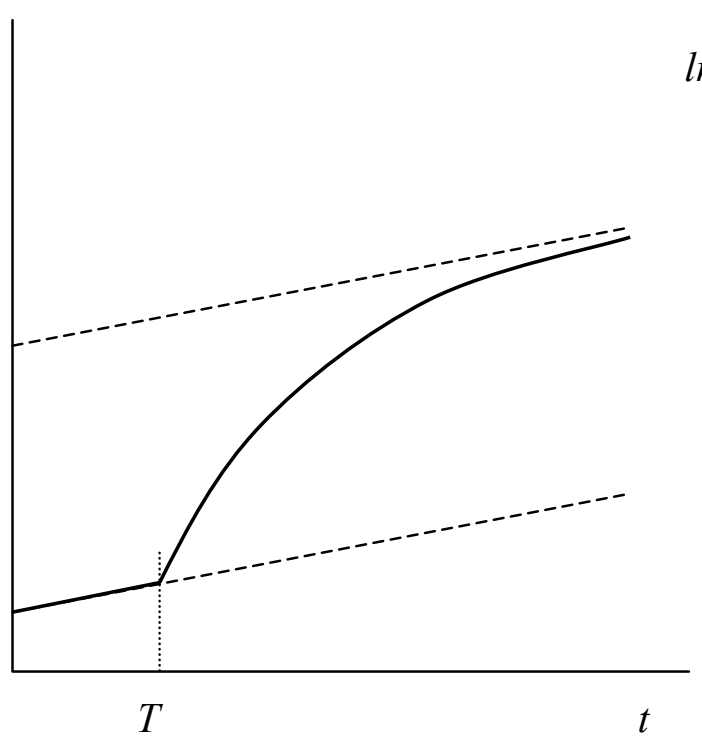

(a) Neoclassical growth model

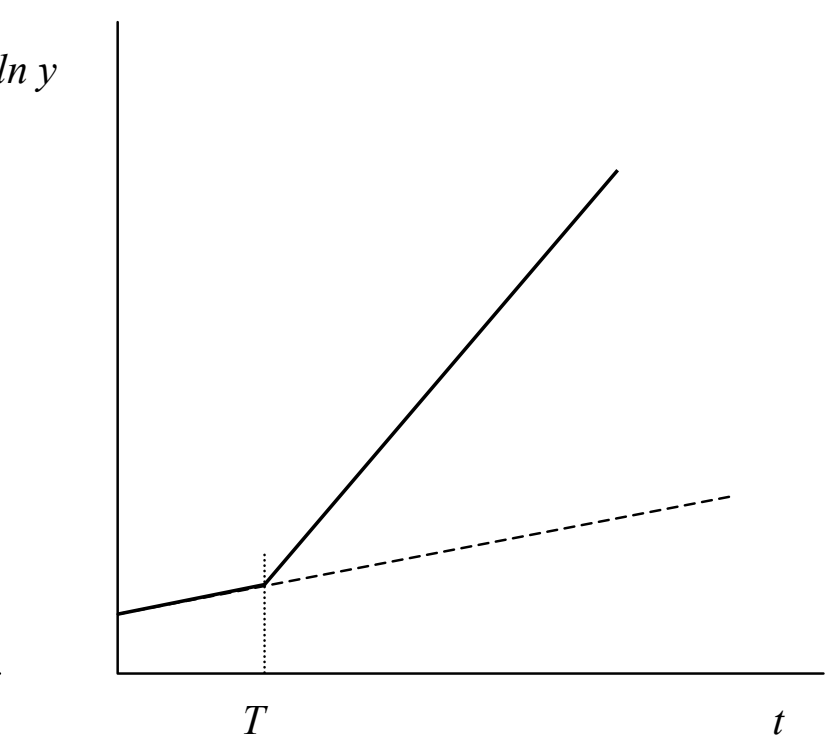

(c) Endogenous growth model

Figure 1.1: Effect of improvement in growth fundamentals at time $T$

They may also be concerned about the fact that growth regressions are based on very strong assumptions about a single linear model being appropriate for all countries in all states. There are a large number of models in which countries can be in different "states" and can switch from state to state responding to factors that determine their longrun equilibrium. For instance, in models with "poverty traps" the relationship between policy variables and growth outcomes is not linear as a movement across a threshold can cause a switch from a "trap" state to a growth state.

Rather than postulate a common model of output determination and dynamics we address these issues head on in this paper with empirical methods that begin by identifying growth episodes and then examine their determinants. We define a growth acceleration as an increase in per-capita growth of 2 percentage points or more (with most of the episodes we identify exceeding this threshold by a wide margin). To qualify as an acceleration, the increase in growth has to be sustained for at least eight years and the post-acceleration growth rate has to be at least 3.5 percent per year. In addition, to rule out cases of pure recovery, we require that post-acceleration output exceed the preepisode peak level of income. Using this approach, we develop some new stylized facts about growth accelerations as well as analyze their predictability.

Our basic results are as follows. First, we find that growth accelerations are quite frequent. Using Penn World Tables data we identify more than 80 episodes of rapid acceleration in economic growth that are sustained for at least eight years. The unconditional probability that a country will experience a growth acceleration sometime 
during a decade is around 25 percent. Second, we find that growth accelerations tend to be correlated with increases in investment and trade, and with real exchange rate depreciations. Third, political-regime changes are statistically significant predictors of growth accelerations. Fourth, the nature of other determinants depends to some extent on whether the acceleration is sustained into the longer term or not. External shocks tend to produce growth accelerations that eventually fizzle out, while economic reform is a statistically significant predictor of growth accelerations that are sustained. Finally, and perhaps most importantly, we find that growth accelerations tend to be highly unpredictable: the vast majority of growth accelerations are unrelated to standard determinants such as political change and economic reform, and most instances of economic reform do not produce growth accelerations.

The plan of the paper is as follows. In section 2, we develop a filter to identify the instances in which countries experienced growth accelerations and discuss the resulting sample. We also present some robustness analyses, including the use of the World Development Indicators dataset in lieu of the Penn World Tables. Section 3 discusses the basic characteristics of growth accelerations and their correlates. Section 4 explores the predictors of growth transitions. Section 5 concludes.

\section{Methods, descriptive statistics and robustness}

\section{A) Methods and descriptive statistics}

We define the growth rate $g_{t}$ at time $t$ over horizon $n$ to be the least squares growth rate of GDP per capita $(y)$ from $t$ to $t+n\left(\hat{g}_{t, t+n}\right)$ defined implicitly by the following:

$$
\ln \left(y_{t+i}\right)=a+\hat{g}_{t, t+n} * t, \quad i=0, . ., n
$$

The change in the growth rate at time $t$ is simply the change in the growth over horizon $n$ across that period:

$$
\Delta g_{t}=g_{t, t+n}-g_{t-n, t}
$$

We identify growth accelerations by looking for rapid growth episodes that satisfy the following conditions.
1) $g_{t, t+n} \geq 3.5 \mathrm{ppa}$
Growth is rapid
2) $\Delta g_{t} \geq 2.0 \mathrm{ppa}$
Growth accelerates
3) $y_{t+n} \geq \max \left\{y_{i}\right\}, i \leq t$
Post-growth output exceeds pre-episode peak

We take the relevant time horizon to be eight years (i.e., $n=7$ ). 
The timing of the initiation of the growth acceleration is chosen by finding the year that maximizes the F-statistic of a spline regression with a break at the relevant year. That is, since for some countries there are a number of consecutive years for which these criteria of a growth episode are met, the "best" starting date is chosen by looking for the best fit among all contiguous eligible dates. Countries can have more than one instance of growth acceleration as long as the dates are more than 5 years apart (so a country could accelerate from $0 \%$ to $3.5 \%$ in 1967 and then accelerate from $3.5 \%$ to $6.0 \%$ in 1972 as two distinct episodes).

We use the Penn World Tables (PWT) 6.1 as our baseline data source since this gives us data that go back to 1950. We eliminate from our sample all countries with population less than 1 million, as well as all countries with fewer than 20 data points in PWT. Since $n=7$, the earliest and latest years for which we can identify episodes are 1957 and 1992, respectively.

This filter yields a surprisingly large number of growth accelerations -83 episodes in all. Table 2.1 shows all of these episodes with the standard three-letter country abbreviation and the year of initiation. The table is grouped by region and decade and within each sorted by the magnitude of the growth acceleration. It is comforting to see that our method identifies most of the well-known episodes of growth acceleration that are commonly associated with discrete political changes or policy reforms (e.g. China 1978, Argentina 1990, Mauritius 1971, Korea 1962, Indonesia 1967, Brazil 1967, Chile 1986, Uganda 1989). But the fact that there are so many instances of rapid growth indicates that growth accelerations are often produced by less noticable changes. This is a point we will develop further when we turn to the analysis of determinants.

Aside from the sheer number of accelerations, the magnitude of the typical acceleration is also striking. Conditional on a growth acceleration of at least 2 ppa, the average acceleration was $4.7 \mathrm{ppa}$ (median 4.0). This implies that in the typical episode output stood almost 40 percent higher at the end of the episode than it would have been without any acceleration. Moreover, there are many episodes of accelerations of 7 percentage points or more (e.g. Ghana 1965 (8.4), Pakistan 1962 (7.1), Argentina 1990 $(9.2))$.

We estimate the (unconditional) probability of a growth acceleration by dividing the number of episodes by the number of country-years in which an episode could have occurred. The latter is calculated by summing up all the country-years in our sample and eliminating a 4-year window after the occurrence of each episode, since our filter takes this period as belonging to the same episode. Applying this rule we obtain 3097 possible occasions in which an episode could have occurred. Dividing our 83 episodes by this number we get that the average probability of a growth transition in our sample is about 2.7 percent per year. This means that a typical country would have about a 25 percent chance of experiencing a growth transition at some point in any given decade. 


\begin{tabular}{|c|c|c|c|c|c|c|}
\hline Region & Decade & Country & Year & $\begin{array}{r}\text { Growth } \\
\text { before }\end{array}$ & $\begin{array}{r}\text { Growth } \\
\text { after }\end{array}$ & $\begin{array}{r}\text { Difference } \\
\text { in growth }\end{array}$ \\
\hline \multirow{20}{*}{$\begin{array}{l}\text { Sub- } \\
\text { Saharan } \\
\text { Africa }\end{array}$} & \multirow{7}{*}{$\begin{array}{l}1950 \text { s and } \\
1960 \text { s }\end{array}$} & NGA & 1967 & -1.7 & 7.3 & 9.0 \\
\hline & & BWA & 1969 & 2.9 & 11.7 & 8.8 \\
\hline & & GHA & 1965 & -0.1 & 8.3 & 8.4 \\
\hline & & GNB & 1969 & -0.3 & 8.1 & 8.4 \\
\hline & & ZWE & 1964 & 0.6 & 7.2 & 6.5 \\
\hline & & $\mathrm{COG}$ & 1969 & 0.9 & 5.4 & 4.5 \\
\hline & & NGA & 1957 & 1.2 & 4.3 & 3.0 \\
\hline & \multirow[t]{9}{*}{$1970 \mathrm{~s}$} & MUS & 1971 & -1.8 & 6.7 & 8.5 \\
\hline & & TCD & 1973 & -0.7 & 7.3 & 8.0 \\
\hline & & CMR & 1972 & -0.6 & 5.3 & 5.9 \\
\hline & & $\mathrm{COG}$ & 1978 & 3.1 & 8.2 & 5.1 \\
\hline & & UGA & 1977 & -0.6 & 4.0 & 4.6 \\
\hline & & LSO & 1971 & 0.7 & 5.3 & 4.6 \\
\hline & & RWA & 1975 & 0.7 & 4.0 & 3.3 \\
\hline & & MLI & 1972 & 0.8 & 3.8 & 3.0 \\
\hline & & MWI & 1970 & 1.5 & 3.9 & 2.5 \\
\hline & \multirow{4}{*}{$\begin{array}{l}\text { 1980s and } \\
1990 \mathrm{~s}\end{array}$} & GNB & 1988 & -0.7 & 5.2 & 5.9 \\
\hline & & MUS & 1983 & 1.0 & 5.5 & 4.4 \\
\hline & & UGA & 1989 & -0.8 & 3.6 & 4.4 \\
\hline & & MWI & 1992 & -0.8 & 4.8 & 5.6 \\
\hline \multirow[t]{4}{*}{ South Asia } & $1950 \mathrm{~s} / 60 \mathrm{~s}$ & PAK & 1962 & -2.4 & 4.8 & 7.1 \\
\hline & \multirow[t]{2}{*}{$1970 \mathrm{~s}$} & PAK & 1979 & 1.4 & 4.6 & 3.2 \\
\hline & & LKA & 1979 & 1.9 & 4.1 & 2.2 \\
\hline & $1980 \mathrm{~s}$ & IND & 1982 & 1.5 & 3.9 & 2.4 \\
\hline \multirow[t]{13}{*}{ East Asia } & \multirow{5}{*}{$\begin{array}{l}\text { 1950s and } \\
1960 \mathrm{~s}\end{array}$} & THA & 1957 & -2.5 & 5.3 & 7.8 \\
\hline & & KOR & 1962 & 0.6 & 6.9 & 6.3 \\
\hline & & IDN & 1967 & -0.8 & 5.5 & 6.2 \\
\hline & & SGP & 1969 & 4.2 & 8.2 & 4.0 \\
\hline & & TWN & 1961 & 3.3 & 7.1 & 3.8 \\
\hline & \multirow[t]{2}{*}{$1970 \mathrm{~s}$} & $\mathrm{CHN}$ & 1978 & 1.7 & 6.7 & 5.1 \\
\hline & & MYS & 1970 & 3.0 & 5.1 & 2.1 \\
\hline & \multirow{6}{*}{$\begin{array}{l}\text { 1980s and } \\
1990 \text { s }\end{array}$} & MYS & 1988 & 1.1 & 5.7 & 4.6 \\
\hline & & THA & 1986 & 3.5 & 8.1 & 4.6 \\
\hline & & PNG & 1987 & 0.3 & 4.0 & 3.7 \\
\hline & & KOR & 1984 & 4.4 & 8.0 & 3.7 \\
\hline & & IDN & 1987 & 3.4 & 5.5 & 2.1 \\
\hline & & $\mathrm{CHN}$ & 1990 & 4.2 & 8.0 & 3.8 \\
\hline
\end{tabular}




\begin{tabular}{|c|c|c|c|c|c|c|}
\hline Region & Decade & Country & Year & $\begin{array}{r}\text { Growth } \\
\text { before }\end{array}$ & $\begin{array}{r}\text { Growth } \\
\text { after }\end{array}$ & $\begin{array}{l}\text { Difference } \\
\text { in growth }\end{array}$ \\
\hline \multirow{17}{*}{$\begin{array}{l}\text { Latin } \\
\text { America } \\
\text { and } \\
\text { Caribbean }\end{array}$} & \multirow{7}{*}{$\begin{array}{l}1950 \mathrm{~s} \text { and } \\
1960 \mathrm{~s}\end{array}$} & DOM & 1969 & -1.1 & 5.5 & 6.6 \\
\hline & & BRA & 1967 & 2.7 & 7.8 & 5.1 \\
\hline & & PER & 1959 & 0.8 & 5.2 & 4.4 \\
\hline & & PAN & 1959 & 1.5 & 5.4 & 3.9 \\
\hline & & NIC & 1960 & 0.9 & 4.8 & 3.8 \\
\hline & & $\mathrm{ARG}$ & 1963 & 0.9 & 3.6 & 2.7 \\
\hline & & $\mathrm{COL}$ & 1967 & 1.6 & 4.0 & 2.4 \\
\hline & \multirow[t]{5}{*}{$1970 \mathrm{~s}$} & $\mathrm{ECU}$ & 1970 & 1.5 & 8.4 & 6.8 \\
\hline & & PRY & 1974 & 2.6 & 6.2 & 3.7 \\
\hline & & TTO & 1975 & 1.9 & 5.4 & 3.5 \\
\hline & & PAN & 1975 & 2.6 & 5.3 & 2.7 \\
\hline & & URY & 1974 & 1.5 & 4.0 & 2.6 \\
\hline & \multirow{5}{*}{$\begin{array}{l}1980 \mathrm{~s} \text { and } \\
1990 \mathrm{~s}\end{array}$} & CHL & 1986 & -1.2 & 5.5 & 6.7 \\
\hline & & URY & 1989 & 1.6 & 3.8 & 2.1 \\
\hline & & HTI & 1990 & -2.3 & 12.7 & 15.0 \\
\hline & & $\mathrm{ARG}$ & 1990 & -3.1 & 6.1 & 9.2 \\
\hline & & DOM & 1992 & 0.4 & 6.3 & 5.8 \\
\hline \multirow{10}{*}{$\begin{array}{l}\text { Middle } \\
\text { East and } \\
\text { North } \\
\text { Africa }\end{array}$} & \multirow{5}{*}{$\begin{array}{l}\text { 1950s and } \\
1960 \mathrm{~s}\end{array}$} & MAR & 1958 & -1.1 & 7.7 & 8.8 \\
\hline & & SYR & 1969 & 0.3 & 5.8 & 5.5 \\
\hline & & TUN & 1968 & 2.1 & 6.6 & 4.5 \\
\hline & & ISR & 1967 & 2.8 & 7.2 & 4.4 \\
\hline & & ISR & 1957 & 2.2 & 5.3 & 3.1 \\
\hline & \multirow[t]{4}{*}{$1970 \mathrm{~s}$} & JOR & 1973 & -3.6 & 9.1 & 12.7 \\
\hline & & EGY & 1976 & -1.6 & 4.7 & 6.3 \\
\hline & & SYR & 1974 & 2.6 & 4.8 & 2.2 \\
\hline & & DZA & 1975 & 2.1 & 4.2 & 2.1 \\
\hline & $\begin{array}{l}1980 \mathrm{~s} \text { and } \\
1990 \mathrm{~s}\end{array}$ & SYR & 1989 & -2.9 & 4.4 & 7.3 \\
\hline \multirow[t]{17}{*}{ OECD } & \multirow{11}{*}{$\begin{array}{l}1950 \mathrm{~s} \text { and } \\
1960 \mathrm{~s}\end{array}$} & ESP & 1959 & 4.4 & 8.0 & 3.5 \\
\hline & & DNK & 1957 & 1.8 & 5.3 & 3.5 \\
\hline & & JPN & 1958 & 5.8 & 9.0 & 3.2 \\
\hline & & USA & 1961 & 0.9 & 3.9 & 3.0 \\
\hline & & CAN & 1962 & 0.6 & 3.6 & 2.9 \\
\hline & & IRL & 1958 & 1.0 & 3.7 & 2.7 \\
\hline & & BEL & 1959 & 2.1 & 4.5 & 2.4 \\
\hline & & NZL & 1957 & 1.5 & 3.8 & 2.4 \\
\hline & & AUS & 1961 & 1.5 & 3.8 & 2.3 \\
\hline & & FIN & 1958 & 2.7 & 5.0 & 2.2 \\
\hline & & FIN & 1967 & 3.4 & 5.6 & 2.2 \\
\hline & \multirow{6}{*}{$\begin{array}{l}\text { 1980s and } \\
1990 \mathrm{~s}\end{array}$} & PRT & 1985 & 1.1 & 5.4 & 4.3 \\
\hline & & ESP & 1984 & 0.1 & 3.8 & 3.7 \\
\hline & & IRL & 1985 & 1.6 & 5.0 & 3.4 \\
\hline & & GBR & 1982 & 1.1 & 3.5 & 2.5 \\
\hline & & FIN & 1992 & 1.0 & 3.7 & 2.8 \\
\hline & & NOR & 1991 & 1.4 & 3.7 & 2.2 \\
\hline
\end{tabular}


Another way of expressing the high rate of occurrence of growth accelerations is to note the proportion of countries that experience at least one such episode. Our data set allows us to search for growth accelerations for a total of 110 countries during the 36year period between 1957 and 1992. (Note however that for many countries we are restricted to a shorter span of time.) Of these, 60 (or 54.5\%) have experienced at least one growth acceleration and 23 (or $20.9 \%$ ) have experienced two accelerations.

Table 2.2 presents the number and probability of growth accelerations by region and decade. Looking at the growth experience by decades requires two caveats. The decade of the 1950s and 1990s have substantially fewer observations than the thirty intervening years. In the case of the 1990s, the absence is due to the fact that our filter requires the calculation of post-transition rates of growth, which means our last feasible year is 1992 . In the case of the 1950 s, the reason is the lack of pre-transition growth rates as well as the fact that many developing countries are absent from the dataset. With these caveats about the 1950s and 1990s, growth transitions exhibit a declining trend that may have been partially reversed in the 1990s.

If we look at the experience by regions, the largest number of growth accelerations is in Asia, with 21 occurrences and an average probability of a growth transition of 4.3 percent for the full-sample period. We identified 18 growth accelerations in Africa, many more than one commonly associates with this continent, but that still adds up to the lowest probability of a growth transition of all the regions: only 1.97 percent. We identified 17 growth transitions in Latin America but this adds to a belowaverage probability of 2.48 percent. We identified 12 growth transitions in Europe, but 5 of them were in the 1950s when the region was recovering from WWII. Europe's overall probability of a growth transition was 2.43 percent but with a rising trend in the $1980 \mathrm{~s}$ and $1990 \mathrm{~s}$ after very low numbers in the $60 \mathrm{~s}$ and $70 \mathrm{~s}$. There are 10 growth transitions in the Middle East and North Africa which add up to the second highest probability. However, 9 of the transitions took place before 1980 and are presumably associated with oil booms.

Table 2.2: Frequency of growth episodes (\%)

Number of growth episodes divided by number of datapoints in that decade and region

\begin{tabular}{|c|c|c|c|c|c|c|c|c|c|}
\hline & & & & Region & & & & & \\
\hline Decade & Asia & Africa & Mid. E & Europe & Latin A & Other & Total & Episodes & Observations \\
\hline 1950 's & 8.33 & 6.25 & 16.67 & 12.82 & 3.57 & 14.29 & 8.44 & 13 & 154 \\
\hline 1960's & 5.13 & 3.70 & 4.48 & 0.76 & 2.63 & 8.70 & 3.33 & 23 & 691 \\
\hline 1970's & 2.86 & 2.51 & 5.26 & 0.00 & 2.66 & 2.33 & 2.42 & 23 & 952 \\
\hline 1980's & 4.43 & 0.56 & 1.02 & 2.78 & 0.92 & 0.00 & 1.56 & 16 & 1026 \\
\hline 1990's & 2.50 & 1.14 & 0.00 & 4.26 & 5.26 & 5.56 & 2.92 & 8 & 274 \\
\hline Total & 4.09 & 1.91 & 3.61 & 2.34 & 2.40 & 3.55 & 2.68 & 83 & 3097 \\
\hline Episodes & 21 & 18 & 10 & 12 & 17 & 5 & 83 & & \\
\hline Observations & 514 & 944 & 277 & 513 & 708 & 141 & 3,097 & & \\
\hline
\end{tabular}


Since we are interested in both the initiation of episodes of rapid growth and in whether or not the rapid growth is sustained, we also calculate the growth rates starting eight years after the initiation of the episode. Obviously the longer the time period we consider after the initiation of a growth episode, the more we lose recent accelerations. Table 2.3 presents the growth episodes by their growth rate in the seven years preceding their growth acceleration and in the ten years following their episode of growth acceleration (i.e., in years $[t+7, t+17]$ ).

This exercise distinguishes those episodes that were and were not sustained into the longer term. We choose 2 percent growth as our threshold as this is (roughly) the OECD average over the long term and hence is the rate which a country would need to grow to converge with the industrial countries. Of the 69 growth episodes for which this calculation can be undertaken, 16 had negative growth after the end of the episode, 16 had slow growth (between 0 and 2) and 37 had rapid growth. Figure 2.1 shows six examples in which growth was sustained at a rapid pace after the first eight years of fast growth.

Figure 2.2 shows six examples of countries that experienced growth acceleration followed by negative growth (Nigeria, Trinidad and Tobago, Algeria) or slow growth (Colombia, Brazil). Pakistan is an interesting case, as it had two episodes, one in 1962, which was initiated from falling output in the previous seven years and was followed by slow growth in the 1970s (1.8 ppa), and then another episode of rapid growth in 1979, which was followed by growth of $2.3 \mathrm{ppa}$ in the 1990s.

Table 2.3 also distinguishes between those episodes that began from negative, slow, or above average growth. While 15 of these 69 episodes were preceded by falling output, 22/69 were initiated from slow and 32 of 60 from above average growth.

Countries on the upper left hand corner had negative growth before and after the growth episode. As can be seen, this group is dominated by African countries. Countries in the lower row had high growth after the eight-year period. This group is dominated by East Asian and European countries. This differentiation suggests that it would be interesting to inquire about the determinants of whether a given growth acceleration is sustained or not after the initial eight-year period. We will look more deeply into this in section 4. 


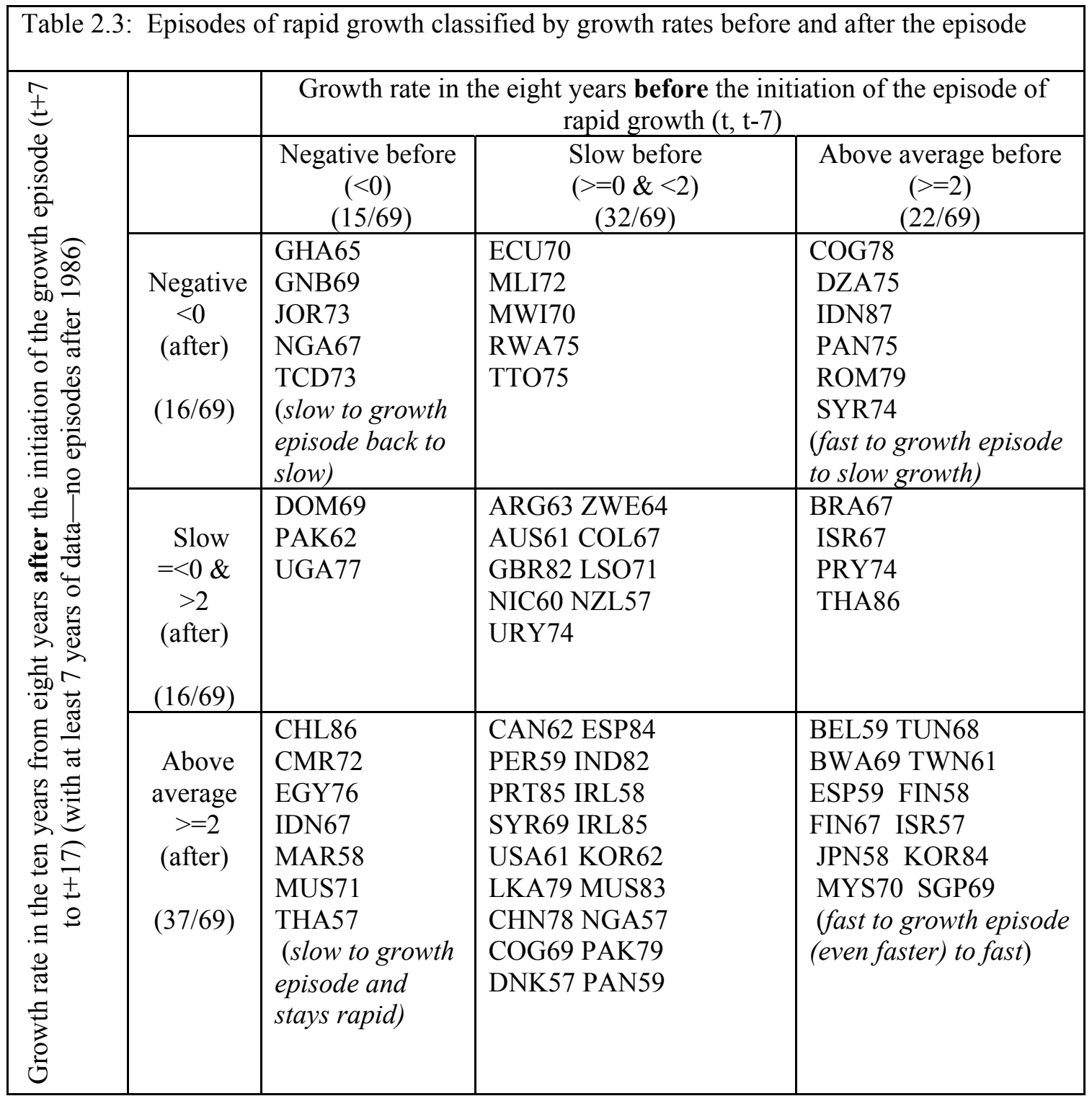


Figure 2.1: Examples of growth episodes that were sustained
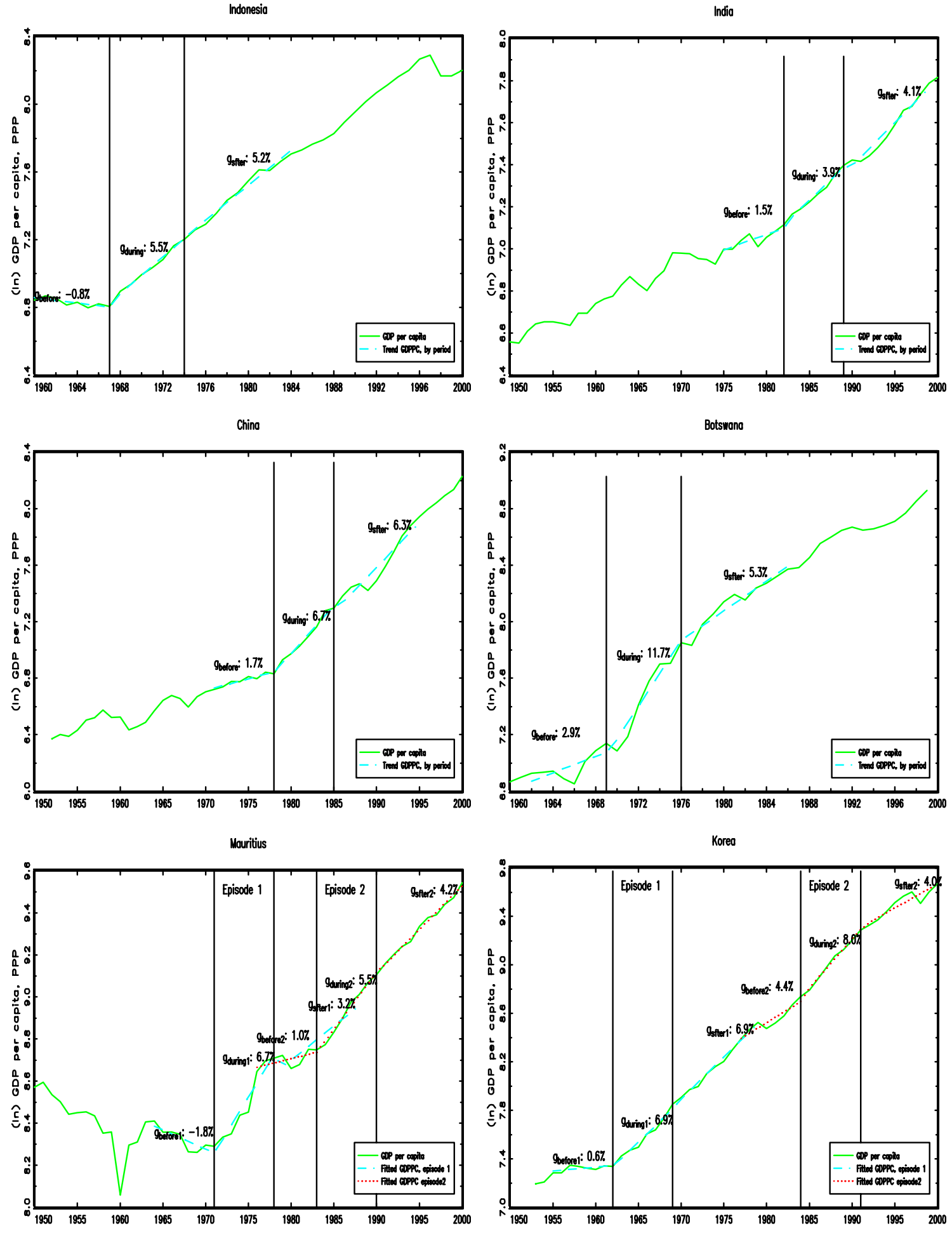
Figure 2.2: Examples of growth episodes that were not sustained
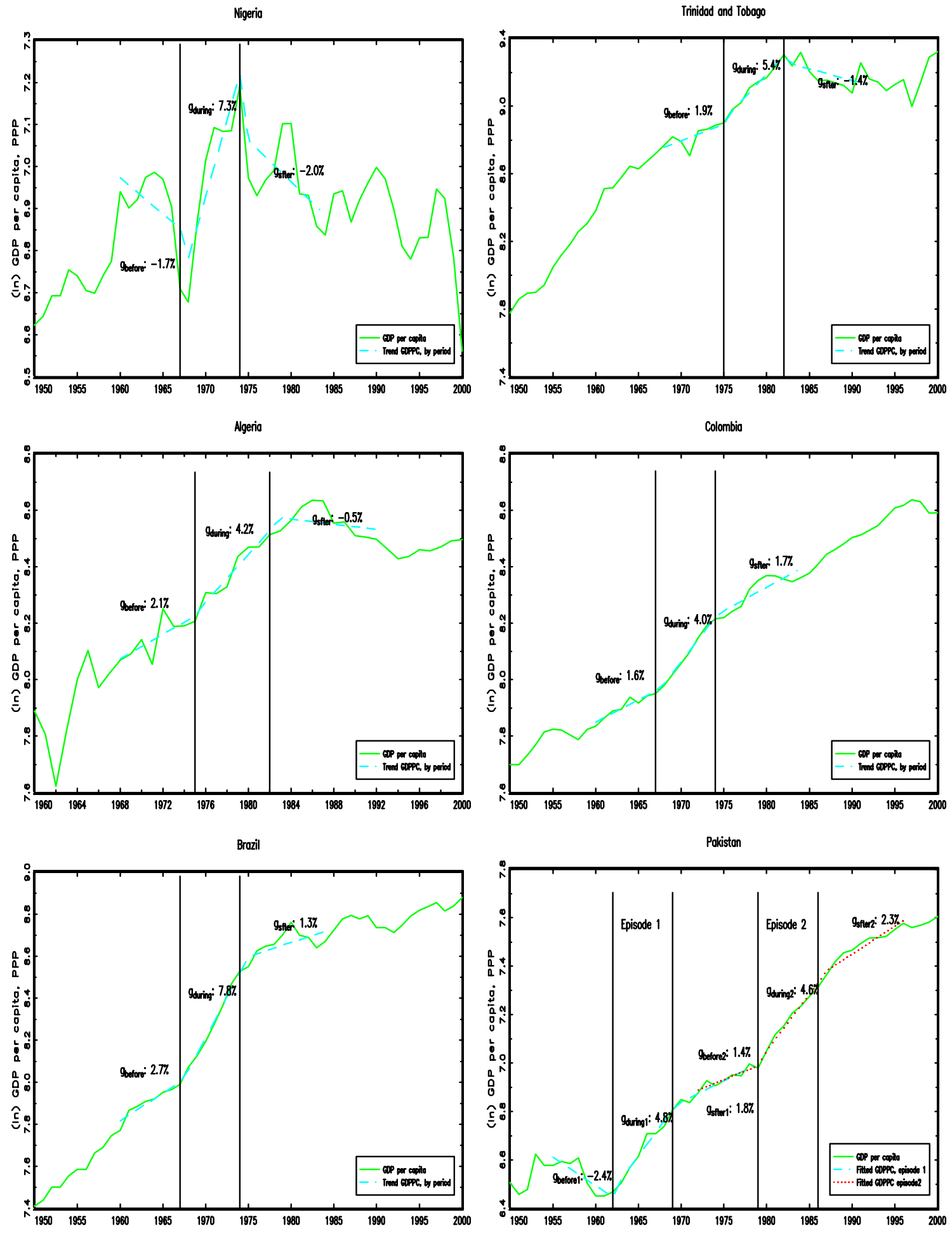


\section{B) Robustness of the definition of a growth episode.}

Before launching into further analysis of the correlates of growth episodes we will discuss three issues with the robustness of our method of identifying growth accelerations: (a) the parameters that define a growth episode, (b) the data used, and (c) statistical issues.

Parameters of the "filter". We can illustrate the function of the filter by showing graphically the initiation of a growth episode and then three examples of countries that meet one or more but not all of the conditions. A classic growth acceleration is Indonesia in 1967. In the years before 1967 growth was -0.8 ppa while in the eight years after 1967 growth was $5.5 \mathrm{ppa}$, for a growth acceleration of 6.3 percentage points.

The key element in the filter is the combination of both a high level of growth and a significant acceleration of growth. There are many cases in which growth improves substantially but does not reach the threshold of "rapid." Using an eight-year period and the thresholds of 3.5 ppa growth and a 2.0 ppa increase are defensible, but admittedly arbitrary. Obviously shortening the horizon of eight years identifies far more episodes than 83. For example, using five-year growth rates identifies 125 episodes versus only 37 using ten-year horizons.

Tightening or relaxing the thresholds of the filter produces the expected results. If the threshold for change is 2 ppa but the growth threshold is raised to 4.0 ppa then only 68 episodes are identified versus 90 if the threshold is 3.0. With the threshold for absolute growth at $3.5 \mathrm{ppa}$, raising the acceleration threshold to 2.5 yields only 67 episodes while lowering it to 1.5 identifies 93 episodes. We shall present a set of robustness checks with these varying cutoffs when we discuss the predictability of growth accelerations in section 4.

In a similar exercise of examining the determinants of growth breaks (but which does not distinguish between accelerations and decelerations) Jones and Olken (2004a) use an algorithm that allows an arbitrary number of breaks and does not constrain these to be separated by any given number of years. This has the expected effect of allowing many "breaks" quite close together-so, while we identify one acceleration in Uganda's growth (in 1989) their method allows three breaks within 5 years.

Data. Unless otherwise noted we use the Penn World Tables version 6.1 data. In order to be sure that our estimates of growth episodes were robust to using a different series for GDP per capita we also implemented exactly the same procedures using data from the World Bank's World Development Indicators (see Table 2.4). Since the WDI data begin in 1960, 27 of the 83 episodes lack adequate data for comparison. Of the 56 possible episodes for which there are WDI data 25 (45\%) are identified as episodes with exactly the same dates, $15(27 \%)$ are identified as episodes with dates of initiation

differing by two years or less and another $6(11 \%)$ are identified as episodes - but with 
dates of initiation differing by more than two years. ${ }^{1}$ So on $81 \%$ of the 56 episodes there is agreement on the basics. We take this to be encouraging.

Ten of the 56 PWT-identified episodes produce different results when WDI data are used. Four of the PWT episodes show an acceleration of growth but either do not meet the threshold for rapid growth of 3.5\% (MWI, GNB) or the change in growth is less than 2 points (MYS, URY). This leaves six episodes on which the data sources just disagree, including four instances in which the PWT data suggest an acceleration and the WDI data show a fall in growth.

\begin{tabular}{|c|c|c|c|c|c|c|c|c|}
\hline & \multicolumn{4}{|c|}{ PWT 6.2 Data } & & \multicolumn{3}{|c|}{ WDI data } \\
\hline & & $\begin{array}{l}\text { Growth } \\
\text { before }\end{array}$ & $\begin{array}{l}\text { Growth } \\
\text { after }\end{array}$ & $\begin{array}{l}\text { Difference } \\
\text { in growth }\end{array}$ & & $\begin{array}{l}\text { Growth } \\
\text { before }\end{array}$ & $\begin{array}{l}\text { Growth } \\
\text { after }\end{array}$ & $\begin{array}{l}\text { Difference in } \\
\text { Growth }\end{array}$ \\
\hline MWI & 1992 & -0.8 & 4.8 & 5.6 & & -0.6 & 2.0 & 2.6 \\
\hline GNB & 1988 & -0.7 & 5.2 & 5.9 & & -0.7 & 1.5 & 2.2 \\
\hline MYS & 1970 & 3.0 & 5.1 & 2.1 & & 3.4 & 5.2 & 1.8 \\
\hline URY & 1989 & 1.6 & 3.8 & 2.1 & & 1.8 & 3.2 & 1.4 \\
\hline LKA & 1979 & 1.9 & 4.1 & 2.2 & & 3.3 & 3.3 & 0.0 \\
\hline PAN & 1975 & 2.6 & 5.3 & 2.7 & & 2.7 & 2.3 & -0.4 \\
\hline MWI & 1970 & 1.5 & 3.9 & 2.5 & & 3.6 & 2.9 & -0.7 \\
\hline SYR & 1974 & 2.6 & 4.8 & 2.2 & & 5.0 & 4.2 & -0.8 \\
\hline TCD & 1973 & -0.7 & 7.3 & 8.0 & & -1.6 & -3.5 & -1.9 \\
\hline HTI & 1990 & -2.3 & 12.7 & 15.0 & & -1.4 & -5.0 & -3.6 \\
\hline \multicolumn{9}{|c|}{ Episodes identified in WDI data but not in PWT data } \\
\hline CHL & & 1.3 & 3.3 & 2.0 & 1974 & 0.3 & 3.8 & 3.5 \\
\hline KEN & & 2.6 & 4.3 & 1.7 & 1967 & 2.5 & 5.2 & 2.8 \\
\hline CRI & & 1.9 & 3.3 & 1.4 & 1967 & 1.8 & 4.0 & 2.1 \\
\hline SGP & & 3.4 & 4.6 & 1.2 & 1987 & 3.7 & 6.1 & 2.4 \\
\hline LSO & & -1.5 & -0.5 & 1.0 & 1985 & -0.8 & 3.7 & 4.4 \\
\hline GAB & & 7.7 & 4.2 & -3.5 & 1969 & 5.4 & 13.7 & 8.4 \\
\hline
\end{tabular}

Statistical issues. There are two major ways in which we differ from similar literature. Papell and Ben David (1997) examine changes in growth by a similar search over possible breaks in trend and then examine all and only "statistically significant" changes in growth rates. ${ }^{2}$ This is not appropriate for our interests because this will identify growth changes of very different magnitude because of the differing statistical power caused by the underlying variability of the output series. It is possible that if a "statistical significance" cut-off were used two countries with exactly the same magnitude acceleration to exactly the same rate of growth but with different underlying annual volatility could be classified differently. Since we identify growth changes of

\footnotetext{
${ }^{1}$ The episodes are (with PWT then WDI dating): ZWE 64 (67), Korea 62 (67), Paraguay 74 (70), Algeria 75 (71), Egypt 76 (73), China 78 (81).

${ }^{2}$ Bai and Perron (1998) extend this to multiple structural breaks and discuss problems with small sample properties of such tests.
} 
substantial magnitude our 83 episodes are also (almost) all statistically significant. ${ }^{3}$ There could be many "statistically significant" accelerations of growth that we do not classify as episodes, because the increase in growth is economically not meaningful.

The second issue is whether we use a log-linear trends or first differences to estimate growth rates. Perron (1989) and others (Jones and Olken 2004a) have modeled the evolution of output as a I(1) process so that first differences are stationary and hence testing for "breaks" is testing differences in means of first differences. We suspect that for our purposes nothing particularly significant hangs on this distinction in the modeling of the evolution of output.

\section{Growth accelerations: basic results}

At what income levels are growth transitions more likely? Basic convergence stories hold that growth accelerations are more likely for poorer countries. We split the data into income quartiles (Table 3.1) and find that for the period as a whole there is a monotonically declining probability of a growth transition with rising levels of income as would be implied by a global growth process that shows convergence. However, this is not true of all decades. Probabilities slope steeply downwards in the 1970s and were surprisingly flat in the 1990s. In the 1960s the lower half of the distribution performed better than the upper half. ${ }^{4}$ In the 1980s the bottom half did worse than the upper half. These patterns are not unlike the aggregate growth experience by decade, in that the 1960s were a good time for poor countries while the 1980s have been terrible.

Table 3.1: Acceleration probabilities: income quartiles against decade and region

\begin{tabular}{|c|c|c|c|c|c|c|}
\hline \multirow[b]{2}{*}{ Decade } & \multicolumn{4}{|c|}{ Income Quartile (4 is the highest) } & \multirow[b]{2}{*}{ Total } & \multirow[b]{2}{*}{ Episodes } \\
\hline & 1 & 2 & 3 & 4 & & \\
\hline & 8.11 & 5.13 & 10.53 & 10.00 & 8.44 & 13 \\
\hline & 5.26 & 2.89 & 1.75 & 3.41 & 3.33 & 23 \\
\hline & 3.83 & 3.36 & 2.53 & 0.00 & 2.42 & 23 \\
\hline & 1.19 & 1.55 & 1.96 & 1.54 & 1.56 & 16 \\
\hline & 2.99 & 2.90 & 2.90 & 2.90 & 2.92 & 8 \\
\hline Total & 3.41 & 2.70 & 2.60 & 2.03 & 2.68 & 83 \\
\hline Episodes & 26 & 21 & 20 & 16 & 83 & \\
\hline
\end{tabular}

As a precursor to a detailed examination using regression analysis, it is interesting to ask what simple correlates seem to be associated with the start of a growth transition. This can be done by looking at the average value of a certain variable around the date of the growth transition, which we take to be the years $t-1, t$ and $t+1$ where $t$ is the date of the acceleration and compare it to the value of that same variable during the 7 previous

\footnotetext{
${ }^{3}$ At the $10 \%$ level the exceptions of Syria 74, Malawi 70, and Uruguay 89. There are four countries between the 5 and 10 percent significance level (Finland 92, Singapore 69, Uganda 77, Algeria 75).

${ }^{4}$ However, the top quartile did better than the second quartile.
} 
years. We ask the question whether changes in that variable are significantly different from zero. Another aspect we can study is the correlates of growth during a growth transition, in which case we compare the period covered between year $\mathrm{t}$ and year $\mathrm{t}+7$ to the average for the four years prior to the acceleration [t-1 through $t-4]$.

The results for both calculations are presented in Table 3.2. We study investment, exports, imports, the real exchange rate and inflation. We find that growth accelerations coincide with an increase in the export and import ratios which average 10.7 and 8.7 percent respectively, with increases in the investment ratio of 16 percent and by a large real depreciation of 21.7 percent. All these results are highly statistically significant. We do not find, however, that the terms of trade changes at the time of a growth acceleration are significantly different from zero, although the estimated change is positive. We also find a positive but not statistically significant increase in inflation at the time of the transition. This result could mean that some growth accelerations take place in the context of the resolution of a macroeconomic crisis.

If we look instead at these same variables during the 8-year growth acceleration, instead of just around the start of the process we find similar results except for the real exchange rate. Export, import and investment ratios rise by an average of 14.6, 14.2 and 14.9 percent, respectively. However, real exchange rate changes are no longer statistically different from zero and the estimated coefficient is now a fourth of the estimated change at the time of the acceleration.

Obviously, these results do not imply causality. However, it is interesting to note that growth accelerations seem to require more investment, more exports and a more competitive real exchange rate. Hence, they do not seem to happen by pure accelerations in total factor productivity or in the increased import capacity emanating from a greater availability of external funding.

Table 3.2: Correlates of growth accelerations

$\begin{array}{lrrrrrr} & \text { TOT } & \text { Imports } & \text { Exports } & \text { Inflation } & \text { Investment } & \text { RER } \\ \text { Around the start (\%) } & 2.5 & \mathbf{8 . 7} & \mathbf{1 0 . 7} & 434.0 & \mathbf{1 6 . 0} & \mathbf{- 2 1 . 7} \\ \quad & 0.51 & \mathbf{2 . 1 5} & \mathbf{2 . 3 7} & 1.24 & \mathbf{2 . 5 1} & \mathbf{- 3 . 5 4} \\ \text { t-stat } & 0.61 & \mathbf{0 . 0 4} & \mathbf{0 . 0 2} & 0.22 & \mathbf{0 . 0 1} & \mathbf{0 . 0 1} \\ \text { p value } & 41 & \mathbf{4 1} & \mathbf{4 1} & 52 & \mathbf{7 6} & \mathbf{1 1} \\ \text { Number } & & & & & & \\ & 2.8 & \mathbf{1 4 . 2} & \mathbf{1 4 . 6} & -90.7 & \mathbf{1 4 . 9} & -5.2 \\ \text { In the 8-year period (\%) } & 0.66 & \mathbf{3 . 3 6} & \mathbf{4 . 3 5} & -0.51 & \mathbf{4 . 2 5} & -0.71 \\ \text { t-stat } & 0.51 & \mathbf{0 . 0 0} & \mathbf{0 . 0 0} & 0.61 & \mathbf{0 . 0 0} & 0.49 \\ \text { p value } & 45 & \mathbf{5 0} & \mathbf{5 0} & 58 & \mathbf{8 3} & 15 \\ \text { Number } & & & & & \end{array}$

\section{Predictors of growth transitions}


We have shown in the preceding that growth accelerations are a fairly common occurrence. Our data allows us to identify growth episodes over a maximum time span of 35 years (1957-1992) and yields 83 such episodes. Hence in any given year, there are between 2 and 3 new growth transitions that are initiated around the world. In this section, we analyze the predictability of these transitions. In particular, we ask: how well do the standard explanatory variables do in predicting the timing of growth accelerations. We focus on three types of predictors, relating to (a) the external context, (b) domestic economic policies, and (c) political circumstances. We first analyze all growth transitions taken together, and then distinguish between those that are sustained in the longer term and those that aren't.

As we shall see, these three categories of explanatory variables have some leverage in predicting growth transitions. Furthermore, sustained and unsustained growth accelerations tend to be associated with somewhat different triggers. Perhaps the most important conclusion of this section, however, pertains to the unpredictability of growth accelerations. Despite a somewhat liberal interpretation of what predictability means in this context, we find that there is only a loose link between favorable external, economic, or political conditions (as measured by conventional explanatory determinants) and growth accelerations. In particular, standard economic reform packages have marginal effects on the probability that a growth transition will be initiated.

\section{A) Methods and data}

Our dependent variable is a dummy that takes the value of 1 around the time of a growth acceleration (and 0 otherwise). More specifically, we assign a value of 1 to the three years centered on the first year of the growth episode (i.e., the dummy equals 1 for $i$ $=t-1, t$, and $t+1)$. The reason we allow a window around $t$ is that there is a certain amount of uncertainty that attaches to the identification of a specific year of growth acceleration. A 3-year window reduces the probability that we will narrowly miss the timing of an acceleration through quirks in the data or in our method.

Our comparison group for a growth acceleration consists of the countries that have not had a growth episode in that same year. So our sample consists of all countries for which the relevant data are available, including countries that have not experienced growth episodes. We make the following adjustments to the sample. First, for each country, we drop the first and last seven years of data, since growth episodes could not have been calculated for those years. ${ }^{5}$ Second, we drop all data pertaining to years $t+2 \ldots t+7$ of an episode, since we are interested in predicting the timing of accelerations.

We run probits where the dependent variable (the 3-year window around the date of the year of growth acceleration) is regressed on several determinants. We will also present estimates with alternative estimation strategies. All our runs contain a full set of year effects to control for external circumstances that are common to all countries.

\footnotetext{
${ }^{5}$ We could also have dropped data for years in which a growth episode is not initiated $(t-1, t, t+1)$ somewhere in the world. However, this would have no practical effect on our sample since the years $t-1, t$, $t+1$ of growth episodes span the entire sample from 1957 to 1992.
} 
Our explanatory variables can be categorized under three headings.

(i) External shocks. It is plausible that many growth accelerations are triggered by favorable external conditions. To capture this, we rely on a variable that is based on the terms of trade. This is a dummy variable, TOT_Thresh90, which takes the value 1 whenever the change in the terms of trade from year $t$ to $t-4$ is in the upper $90 \%$ of the entire sample. This variable is meant to capture exceptionally favorable external circumstances. We could also have used a variable related to capital inflows, but such flows are endogenous and (presumably) forward-looking, rendering causal inference problematic.

(ii) Political changes. Growth accelerations can also be triggered by changes in the underlying political balance as revealed by transformations in the political regime. We use several variables to measure political regime change. Regchange takes a value of 1 in the five-year period beginning with a regime change as recorded in the Polity IV dataset (Marshall and Jaggers 2002). (Regime change is defined as either a three-unit change in the polity score or as regime interruption.) Poschange is 1 during this five-year period if the regime change increased the Polity score (variable CHANGE in the Polity IV dataset), denoting a movement towards greater democracy. Negchange is defined analogously for a decrease in the polity score, and denotes a move towards greater authoritarianism. ${ }^{6}$

While the Polity variables are the main ones we use, we will also show results with additional political variables. Lead_Death is a dummy for the five-year period starting with a political leader's death. Tenure is an interaction term between Lead_Death and the length of the tenure of the dying ruler. These variables come from Jones and Olken (2004b). War_End is a dummy for the five-year period beginning with the cessation of an armed conflict from the Correlates of War International War Database (Singer and Small 2003). ${ }^{7}$ Civil_War is a dummy for the five-year period beginning with the ending of an armed civil war. ${ }^{8}$

(iii) Economic reform. Perhaps the most important potential determinant from our perspective is a change in economic policy that is conducive to higher economic growth. To quantify such a change in economic policy, we rely primarily on an index that was originally developed by Sachs and Warner (1995) and which has been subsequently revised and updated by Wacziarg and Welch (2003). The Sachs-Warner index was meant to capture changes in an economy's openness to trade, but as argued in Rodriguez and Rodrik (2001), the coding incorporated a number of structural features (e.g. presence of marketing boards, socialist economic regimes) and the macroeconomic environment (e.g. presence of a large black-market premium for foreign currency), in addition to tariff and non-tariff barriers to trade. The Wacziarg-Welch (2003) update

\footnotetext{
${ }^{6}$ Note that any change in the Polity score that is larger in absolute value than 20 (indicating Authority Interruption or Authority Collapse, etc.) is coded as a zero.

${ }^{7}$ This variable is given as yearlef and yearlef 2 in the original Correlates of War International War Database.

${ }^{8}$ This variable is given as yearend 1 and yearend 2 in the original Correlates of War Civil War Database.
} 
continues with the same basic approach. This makes the Sachs-Warner-Wacziar-Welch (SWWW) index a good candidate for a measure that captures broad economic reforms. Hence we code Econ_Lib as a dummy that takes the value of 1 during the first five years of a transition towards "openness" a la SWWW.

In addition, we use a measure of financial liberalization, Finance, which is a dummy for the first five years of a financial liberalization episode. The timing of financial liberalization is taken from Bekaert, Harvey, and Lundblad (2001).

\section{B) Results}

Table 4.1 presents the main probit results. Our baseline specification, shown in column (1), includes the terms-of-trade shock, political regime change, and economic liberalization. The first two of these enter with statistically significant coefficients. According to the estimates, a large positive terms-of-trade shock (as defined above) increases the probability of experiencing a growth acceleration by 4.4 percentage points. A political regime change increases this probability by 5.3 percentage points. In this baseline specification, economic reform does not have a statistically significant impact on growth acceleration, although its estimated coefficient is (as expected) positive.

In the next three columns we probe the political determinants more deeply. Column (2) decomposes the political regime change into a positive (towards democracy) and negative (towards autocracy) component. The striking result is that while both of these are separately significant, the impact of a movement towards autocracy is more than three times larger (10.8 points versus 2.9 points). Column (3) shows that a political leader's death has a negative (but insignificant) impact on the likelihood of a growth acceleration. When the leader's death is interacted with the length of the leader's tenure (column 4), we get stronger results: a leader's death is particularly damaging if that leader has not been in office for very long. According to the estimates in column (4), a leader's death has a positive impact on growth acceleration when his tenure starts to exceed about 10 years.

Column (5) shows that financial liberalization has a strong positive impact on the probability of experiencing a growth acceleration, increasing this probability by 7 percentage points. For some countries, mostly developed ones, the financial liberalization variable is censored at 1980. In column (6), we enter a dummy variable (Finance_Dev) that allows countries with censored values to have a different effect for Finance, and we still get a very strong impact from financial liberalization. Note that the estimated coefficient on economic reform turns negative when Finance is included in the regression (but it remains insignificant). Columns (7), (8) and (9) show that armed conflict (external or internal) does not have a significant effect on the likelihood of a growth acceleration.

Finally, columns (10) and (11) drop the terms of trade variable to regain additional observations (allowing the sample size to rise from 2140 to 2903). The main results are similar. In particular, economic reform remains insignificant and a political 
regime change in the direction of autocracy still shows up as a strong predictor of growth acceleration.

Our baseline results are quite robust to the method of estimation. Table 4.2 displays the results for a series of alternative methods. First, we show the results for probits where standard errors are clustered by individual countries and corrected for heteroskedasticity (column 1). Next we run a Tobit regressions, making use of the actual difference in growth post-acceleration and treating non-episodes as censored at 0 (column 2 ). Third, we show the results from a modified logit framework suggested by King and Zeng (2001) that is designed to better handle rare-ocurrence bias (column 3). Finally, we run a random-effects probit (column 4). The results in all cases are not only qualitatively, but also quantitatively similar. This is reassuring, and suggests that the probit results we reported above are broadly representative.

The probits in Table 4.1 utilize the entire sample of countries, including developed countries. As another kind of robustness check, we present in Table 4.3 the analogous results for a sample that includes only developing countries. In most respects, the findings are quite similar. We note three small changes. First, "positive" political regime change (i.e., democratization) is no longer statistically associated with growth accelerations. It is only movements towards autocracy that enters with a statistically significant and positive coefficient. Second, the estimated impact of financial liberalization is much larger and almost double that found in the previous table. Third, economic reform now enters with a statistically significant coefficient in runs that exclude the terms of trade variable (columns 9 and 10).

Our final set of robustness checks relate to the parameters of the filter and the dataset we use. We discussed in section 2 alternative thresholds and the changes that occur when we use WDI data instead of the PWT. We get a somewhat different set of growth accelerations depending on choices make on each of these. To see how much difference this makes in practice, Table 4.4 shows the results of our baseline specification as we vary the set of growth accelerations. The main message is the robustness of the political determinant. "Negative" political change is uniformly significant, with coefficients that vary from 0.05 to 0.12 . "Positive" political change is almost always significant, but enters with much smaller coefficients. The terms-of-trade variable generally enters with the correct (i.e. positive) sign and is significant, with the exception of two instances when it enters with a negative (but insignificant) coefficient. Economic reform remains insignificant (with the exception of one instance).

We will further analyze and interpret these findings below. But first we want to emphasize the limited success that our right-hand side variables collectively achieve in predicting these major growth turnarounds. Even though many of the explanatory variables are statistically significant, they explain very little of the growth pattern that the data reveal. This point can be made in a number of different ways. For example, the average in-sample predicted probability of growth acceleration generated by our baseline probit conditional on an acceleration having taken place is only 0.101 (compared to an unconditional prediction of 0.066). In other words, our empirical framework yields a 9to-1 odds against a growth takeoff for those takeoffs that actually materialized. 
This reflects the poor match between occurrences of growth takeoffs and favorable external, economic or political circumstances. A lot of takeoffs take place when those conditions appear not to be particularly favorable, at least as measured by standard indicators. And growth takeoffs typically fail to materialize when the conditions are indeed favorable. This is shown more systematically in Table 4.5 which displays the proportions of growth accelerations that are preceded or accompanied by changes in our list of determinants, and, conversely, proportions of changes in the determinants that are accompanied or followed by growth accelerations. ${ }^{9}$ Of particular interest is the predictive power of the economic reform variable (Econ_Lib). Since this variable rarely enters significantly, we know that it does not have great leverage on the timing of growth accelerations. Indeed, the table shows that only 14.5 percent accelerations are associated with economic liberalization - or, equivelently, that 85.5 percent of growth accelerations are not preceded or accompanied by liberalizations. And fewer than one in five episodes (18.2 percent) of economic liberalization are followed by growth take-offs. More than half of growth accelerations are preceded by political-regime changes; on the other hand, only a tiny proportion of political-regime changes $(13.6 \%)$ are followed by growth accelerations.

\section{C) Sustained versus unsustained growth accelerations}

The results we have just discussed reveal some interesting, but also puzzling associations. It is not clear a prori why transitions to autocracy should have more favorable effects on growth accelerations than transitions to democracy. Nor is it clear why financial liberalization should have such a potent impact on the likelihood of growth accelerations when the impact of our broader measure of economic reform is weak at best. It turns out that it is much easier to understand and interpret these results once we distinguish between growth accelerations that are sustained into the longer term and those that are not.

Remember that our growth accelerations are defined for a time horizon of eight years. That is, we require post-transition growth rates to be higher than pre-transition rates by at least 2 percentage points and also to remain above 3.5 percent during this eight-year period. We now make a distinction among accelerations according to whether they were sustained beyond that eight year horizon. We call those episodes where the growth rate remained above 2 percent in years $[t+7, t+17]$ sustained episodes, and those where the growth rate fell below the 2 percent threshold unsustained episodes. Since this classification requires 16 data points beyond the onset of a growth acceleration, not all episodes can be classified as such. ${ }^{10}$ Therefore in the regressions below we have to work with a somewhat smaller sample.

\footnotetext{
${ }^{9}$ As in the probits, we allow for a maximum of five years' lag between a change in the determinant and the growth acceleration. The timing of the latter is the three-year window centered on the dates listed in Table 2.1. Whenever this three-year window overlaps with the five-year window for the determinants, we count it as a case where growth acceleration coincides with one of its determinants.

${ }^{10}$ But we did not automatically exclude all countries that do not have data from $\mathrm{t}+7$ to $\mathrm{t}+17$ to keep the sample reasonable. If a country has data from $t+7$ to $t+13$, the growth rate for $t+7$ to $t+17$ is defined as the annual average growth rate over this time.
} 
The first two columns of Table 4.6 show that the earlier results are more or less replicated in this truncated sample. However, economic reform is now marginally significant, while financial liberalization is marginally insignificant. We next distinguish between sustained and unsustained accelerations and use them in turn as the dependent variable. The results are interesting. The next four columns show that there are significant differences in the determinants of the two types of growth accelerations. Most striking among these differences are the following: (1) Positive terms of trade shocks are conducive only to unsustained episodes; they have no predictive power over sustained episodes. (2) Economic reform has a statistically and quantitatively significant impact on the likelihood of sustained accelerations. (3) Financial liberalization's positive impact is confined to unsustained accelerations. (4) Positive political change (democratization) has a significant impact on sustained episodes but not unsustained episodes.

These results strongly suggest that sustained and unsustained growth accelerations tend to be triggered by different conditions. Financial liberalization and positive external shocks are associated with growth accelerations that eventually fizzle out. Fundamental economic reform and positive political regime change increase the likelihood of sustained accelerations.

However, we need to repeat the same caveat as before: the predictability of these different kinds of growth episodes still remains extremely low. The determinants of growth episodes - whether of the sustained or unsustained kind - are very poorly captured by our explanatory variables. The bottom panel of Table 4.5 shows the relevant numbers. Only 16.2 percent of sustained growth episodes are preceded or accompanied by economic liberalization, while only 9.1 percent of economic liberalizations are followed by sustained growth take-offs. Growth accelerations seem to be driven largely by idiosyncratic causes. To paraphrase Tolstoy, not even happy families are alike.

\section{Conclusions}

We have focused in this paper on instances of significant acceleration in economic growth. We close the paper by reiterating what we think are the two main surprises that come out of our analysis. First, growth accelerations are a fairly frequent occurrence. Of the 110 countries included in the sample, 60 have had at least one acceleration in the 35-year period between 1957 and 1992 - a ratio of 55 percent. Whatever else this may say about growth, it certainly suggests that achieving rapid growth over the medium term is not something that is tremendously difficult and it is well within most countries' reach (see also Rodrik 2003). This is a useful antidote to the pessimism that often pervades policy discussions on growth.

Second, and not unrelated to the previous finding, most growth accelerations are not preceded or accompanied by major changes in economic policies, institutional arrangements, political circumstances, or external conditions. ${ }^{11}$ As we have shown,

\footnotetext{
${ }^{11}$ For a specific instance of this finding, see Rodrik and Subramanian (2004) on India.
} 
standard growth determinants have some statistical leverage over the timing of accelerations. But on the whole those determinants do a very poor job of predicting the turning points. It would appear that growth accelerations are caused predominantly by idiosyncratic, and often small-scale, changes. The search for the common elements in these idiosyncratic determinants - to the extent that there are any - is an obvious area for future research. 


\section{REFERENCES}

Acemoglu, Daron, Simon Johnson, and James A. Robinson, "The Colonial Origins of Comparative Development: An Empirical Investigation," American Economic Review, 91, 5, December 2001, 1369-1401.

Aghion, Philippe, and Steven Durlauf, Handbook of Economic Growth, North-Holland, forthcoming.

Bai, J. and P. Perron, "Estimating and Testing Linear Models with Multiple Structural Changes," Econometrica 66, 47-78 1998.

Barro, Robert J, "Economic Growth in a Cross Section of Countries," Quarterly Journal of Economics 106, 2, 1991, 407-443.

Barro, Robert, and Xavier Sala- i-Martin, “Convergence, ” Journal of Political Economy, 1992.

Bekaert Geert, Campbell Harvey, and Christian Lundblad, "Does Financial Liberalization Spur Growth?" NBER Working Paper No. 8245, April 2001.

Caselli, Francesco, Gerardo Esquivel and Fernando Lefort, "Reopening the Convergence Debate: A New Look at Cross-Country Growth Empirics", Journal of Economic Growth, vol. 1, no. 3, 1996, pp. 363-389.

Durlauf, Steven, "The Convergence Hypothesis After Ten Years," University of Wisconsin at Madison, March 2003.

Easterly, William, "National Policies and Economic Growth: A Reappraisal," New York University, March 2003.

Easterly, William, Kremer, Michael, Pritchett, Lant, and Summers, Lawrence H. "Good Policy or Good Luck? Country Growth Performance and Temporary Shocks," Journal of Monetary Economics, 1993, 32, 459-483.

Islam, Nazrul, "Growth Empirics: A Panel Data Approach", Quarterly Journal of Economics, vol. 110, no.4, 1995, pp. 1127-1170.

Hall, Robert E. and Charles Jones, "Why Do Some Countries Produce So Much More Output per Worker than Others?" Quarterly Journal of Economics, vol. 114, no. 1, February 1999, pp. 83-116

Jones, Benjamin F., and Benjamin A. Olken, "Why Does Growth Start and Stop?" work in progress, Powerpoint version, April 6, 2004 [2004a]. 
Jones, Benjamin F., and Benjamin A. Olken, "Do Leaders Matter? National Leadership and Growth Since World War II," Northwestern and Harvard Universities, March 2004 [2004b].

King, Gary, and Langche Zeng. "Logistic Regression in Rare Events Data," Harvard University, February 16, 2001.

Marshall, Monty G. and Keith Jaggers. 2002. Polity IV Dataset. [Computer file; version p4v2001] College Park, MD: Center for International Development and Conflict Management, University of Maryland).

Ben-David, Dan, and David H. Papell, "Slowdowns and Meltdowns: Postwar Growth Evidence from 74 Countries," NBER Working Papers 6266, 1997.

Perron, Pierre, "The Great Crash, the Oil Price Shock and the Unit Root Hypothesis", Econometrica 58, 1361-1401, 1989.

Pritchett, Lant, "Understanding Patterns of Economic Growth: Searching for Hills among Plateaus, Mountains, and Plains," World Bank Economic Review, 14(2), 2000.

Rodriguez, Francisco, and Dani Rodrik, "Trade Policy and Economic Growth: A Skeptic's Guide to the Cross-National Evidence," NBER Macroeconomics Annual, eds. Ben Bernanke and Kenneth S. Rogoff, MIT Press, Cambridge, MA, 2001.

Rodrik, Dani, “Growth Strategies,” Harvard University, September 2003.

Rodrik, Dani, and Arvind Subramanian, "From Hindu Growth to Productivity Surge: The Mystery of the Indian Growth Transition," Harvard University and IMF, February 2004.

Sachs, Jeffrey, and Andrew Warner, "Economic Convergence and Economic Policies," Brookings Papers on Economic Activity, eds. William Brainard and George Perry, $1: 1995,1-95,108-118$.

Singer, J. David, and Melvin Small, "Correlates of War Project: International and Civil War Data, 1816-1992" [Computer file], Inter-university Consortium for Political and Social Research [distributor], Ann Arbor, Michigan, 1994

Temple, Jonathan, “The new growth evidence," Journal of Economic Literature, March 1999, 37(1), 112-156.

Wacziarg, Romain, and Karen Horn Welch, "Trade Liberalization and Growth: New Evidence," Stanford University, November 2003. 
Table 4.1: Predicting growth accelerations

\begin{tabular}{|c|c|c|c|c|c|c|c|c|c|c|c|}
\hline & (1) & (2) & (3) & (4) & (5) & (6) & (7) & (8) & (9) & (10) & (11) \\
\hline TOT Thresh90 & $\begin{array}{c}0.044 \\
(2.60)^{\star *}\end{array}$ & $\begin{array}{r}0.045 \\
(2.62)^{\star *}\end{array}$ & $\begin{array}{r}0.044 \\
(2.57)^{*}\end{array}$ & $\begin{array}{r}0.042 \\
(2.51)^{*}\end{array}$ & $\begin{array}{r}0.039 \\
(2.59)^{\star \star}\end{array}$ & $\begin{array}{r}0.038 \\
(2.52)^{*}\end{array}$ & $\begin{array}{r}0.038 \\
(2.51)^{*}\end{array}$ & $\begin{array}{r}0.038 \\
(2.55)^{*}\end{array}$ & $\begin{array}{r}0.037 \\
(2.49)^{*}\end{array}$ & & \\
\hline Econ Lib & $\begin{array}{r}0.021 \\
(1.040)\end{array}$ & $\begin{array}{r}0.022 \\
(1.100)\end{array}$ & $\begin{array}{r}0.020 \\
(1.030)\end{array}$ & $\begin{array}{r}0.020 \\
(1.040)\end{array}$ & $\begin{array}{r}-0.012 \\
(0.710)\end{array}$ & $\begin{array}{r}-0.013 \\
(0.790)\end{array}$ & $\begin{array}{r}-0.013 \\
(0.790)\end{array}$ & $\begin{array}{l}-0.013 \\
(0.780)\end{array}$ & $\begin{array}{l}-0.008 \\
(0.490)\end{array}$ & $\begin{array}{r}0.019 \\
(1.060)\end{array}$ & $\begin{array}{r}0.020 \\
(1.120)\end{array}$ \\
\hline RegChange & $\begin{array}{r}0.053 \\
(4.74)^{\star *}\end{array}$ & & & & & & & & & $\begin{array}{r}0.042 \\
(4.07)^{* *}\end{array}$ & \\
\hline PosChange & & $\begin{array}{r}0.029 \\
(1.97)^{*}\end{array}$ & $\begin{array}{r}0.030 \\
(2.10)^{*}\end{array}$ & $\begin{array}{r}0.027 \\
(1.93)+\end{array}$ & $\begin{array}{r}0.026 \\
(2.08)^{*}\end{array}$ & $\begin{array}{r}0.024 \\
(1.90)+\end{array}$ & $\begin{array}{r}0.024 \\
(1.90)+\end{array}$ & $\begin{array}{r}0.025 \\
(1.96)^{*}\end{array}$ & $\begin{array}{r}0.025 \\
(1.97)^{*}\end{array}$ & & $\begin{array}{r}0.010 \\
(0.700)\end{array}$ \\
\hline NegChange & & $\begin{array}{r}0.108 \\
(5.80)^{\star *}\end{array}$ & $\begin{array}{r}0.108 \\
(5.83)^{\star *}\end{array}$ & $\begin{array}{c}0.108 \\
(5.85)^{\star \star}\end{array}$ & $\begin{array}{r}0.088 \\
(5.33)^{\star *}\end{array}$ & $\begin{array}{r}0.084 \\
(5.22)^{\star *}\end{array}$ & $\begin{array}{r}0.085 \\
(5.24)^{\star *}\end{array}$ & $\begin{array}{r}0.089 \\
(5.47)^{\star *}\end{array}$ & $\begin{array}{r}0.091 \\
(5.46)^{\star *}\end{array}$ & & $\begin{array}{r}0.100 \\
(5.83)^{\star *}\end{array}$ \\
\hline Leader Death & & & $\begin{array}{r}-0.027 \\
(1.240)\end{array}$ & $\begin{array}{l}-0.057 \\
(1.99)^{*}\end{array}$ & $\begin{array}{r}-0.007 \\
(0.150)\end{array}$ & $\begin{array}{r}-0.008 \\
(0.170)\end{array}$ & $\begin{array}{r}-0.008 \\
(0.170)\end{array}$ & $\begin{array}{l}-0.008 \\
(0.160)\end{array}$ & $\begin{array}{l}-0.009 \\
(0.200)\end{array}$ & & \\
\hline Tenure & & & & $\begin{array}{r}0.006 \\
(2.12)^{*}\end{array}$ & $\begin{array}{c}-0.036 \\
(2.92)^{\star \star}\end{array}$ & $\begin{array}{c}-0.038 \\
(2.83)^{\star \star}\end{array}$ & $\begin{array}{c}-0.038 \\
(2.83)^{\star *}\end{array}$ & $\begin{array}{l}-0.038 \\
(2.81)^{\star *}\end{array}$ & $\begin{array}{l}-0.037 \\
(2.94)^{* *}\end{array}$ & & \\
\hline Finance & & & & & $\begin{array}{c}0.071 \\
(2.79)^{\star *}\end{array}$ & $\begin{array}{r}0.105 \\
(2.71)^{\star *}\end{array}$ & $\begin{array}{r}0.105 \\
(2.71)^{\star *}\end{array}$ & $\begin{array}{r}0.108 \\
(2.77)^{\star *}\end{array}$ & & & \\
\hline Finance Dev & & & & & & $\begin{array}{r}-0.026 \\
(1.000)\end{array}$ & $\begin{array}{r}-0.026 \\
(1.000)\end{array}$ & $\begin{array}{r}-0.027 \\
(1.090)\end{array}$ & & & \\
\hline War End & & & & & & & $\begin{array}{r}-0.002 \\
(0.130)\end{array}$ & $\begin{array}{r}0.011 \\
(0.640)\end{array}$ & $\begin{array}{r}0.009 \\
(0.530)\end{array}$ & & \\
\hline Civil War & & & & & & & & $\begin{array}{r}-0.025 \\
(1.380)\end{array}$ & $\begin{array}{r}-0.025 \\
(1.310)\end{array}$ & & \\
\hline $\begin{array}{l}\text { Observations } \\
\text { Growth episodes }\end{array}$ & 2140 & 2140 & 2140 & 2140 & 1902 & 1902 & 1902 & 1902 & 1902 & 2903 & 2903 \\
\hline included & $51 / 83$ & $51 / 84$ & $51 / 85$ & $51 / 86$ & $45 / 81$ & $45 / 82$ & $45 / 83$ & $45 / 84$ & $45 / 85$ & $83 / 83$ & $83 / 38$ \\
\hline Pseudo $R^{\wedge} 2$ & 0.05 & 0.06 & 0.06 & 0.07 & 0.08 & 0.08 & 0.08 & 0.08 & 0.07 & 0.05 & 0.06 \\
\hline
\end{tabular}

Notes: Estimated by probit. Coefficients shown are marginal probabilites evaluated at the sample means.

Numbers in paranthesis are robust t-statistics. All regressions include year dummy variables. See text for sources.

+ indicates significance at the $10 \%$ level, ${ }^{*}$ indicates significance at the $5 \%$ level,

** indicates significance at the $1 \%$ level. 


\begin{tabular}{|c|c|c|c|c|c|}
\hline & Cluster & Tobit & Relogit & Relogit M & RE \\
\hline \multirow[t]{2}{*}{ TOT_thresh90 } & 0.045 & 2.543 & 0.635 & 0.048 & 0.480 \\
\hline & $(1.92)+$ & $(2.24)^{*}$ & $(2.69)^{\star \star}$ & & $(2.92)^{\star \star}$ \\
\hline \multirow[t]{3}{*}{ Econ Lib } & 0.022 & 1.494 & 0.372 & 0.023 & 0.053 \\
\hline & $(0.70)$ & (1.10) & (1.29) & & $(0.26)$ \\
\hline & 0.029 & 2.176 & 0.439 & 0.031 & 0.291 \\
\hline \multirow{2}{*}{ Poschange } & (1.35) & $(2.22)^{*}$ & $(1.83)+$ & & $(1.95)+$ \\
\hline & 0.108 & 5.821 & 1.255 & 0.125 & 1.053 \\
\hline Negchange & $(3.62)^{\star *}$ & $(5.48)^{\star *}$ & $(6.01)^{* *}$ & & $(6.06)^{* *}$ \\
\hline Obs & 2140 & 2140 & 2140 & & 2140 \\
\hline \multicolumn{6}{|c|}{$\begin{array}{l}\text { Cluster is a dprobit regression with standard errors clustered for each country group and corrected for heterosked } \\
\text { Tobit is a tobit regression where non episodes are coded with a } 0 \text {. There is no correction for heteroskedasticity. } \\
\text { Relogit is a logit model corrected for rare occurance bias as suggested by King and Zeng (2001). } \\
\text { Relogit M are the coefficients of the relogit model given as attributable risk. } \\
\text { This is the expected change in the probability of an episode going from a } 0 \text { in the dependent variable to a } 1 . \\
\text { RE is a probit regression with country random effects. There is no correction for heteroskedasticity. } \\
\text { RE M is the marginal effect given at the mean for the dependent variable of the random effects probit regression. } \\
\text { See also notes from previous table. }\end{array}$} \\
\hline
\end{tabular}


Table 4.3: Predicting growth accelerations (developing countries only) Dependent variable is a dummy for the timing of growth accelerations.

\begin{tabular}{|c|c|c|c|c|c|c|c|c|c|c|}
\hline & (1) & (2) & (3) & (4) & (5) & (6) & (7) & (8) & (9) & (10) \\
\hline TOT Thresh90 & $\begin{array}{r}0.044 \\
(2.34)^{*}\end{array}$ & $\begin{array}{r}0.045 \\
(2.40)^{*}\end{array}$ & $\begin{array}{r}0.044 \\
(2.35)^{\star}\end{array}$ & $\begin{array}{r}0.015 \\
(2.05)^{*}\end{array}$ & $\begin{array}{r}0.047 \\
(2.34)^{*}\end{array}$ & $\begin{array}{r}0.045 \\
(2.16)^{*}\end{array}$ & $\begin{array}{r}0.046 \\
(2.20)^{*}\end{array}$ & $\begin{array}{r}0.046 \\
(2.26)^{*}\end{array}$ & & \\
\hline Econ Lib & $\begin{array}{r}0.038 \\
(1.590)\end{array}$ & $\begin{array}{r}0.037 \\
(1.580)\end{array}$ & $\begin{array}{r}0.034 \\
(1.490)\end{array}$ & $\begin{array}{r}0.013 \\
(1.470)\end{array}$ & $\begin{array}{r}-0.003 \\
(0.130)\end{array}$ & $\begin{array}{r}-0.008 \\
(0.320)\end{array}$ & $\begin{array}{r}-0.009 \\
(0.330)\end{array}$ & $\begin{array}{r}0.002 \\
(0.070)\end{array}$ & $\begin{array}{r}0.040 \\
(1.81)+\end{array}$ & $\begin{array}{r}0.043 \\
(1.96)^{*}\end{array}$ \\
\hline RegChange & $\begin{array}{c}0.043 \\
(3.40)^{\star *}\end{array}$ & & & & & & & & $\begin{array}{r}0.038 \\
(3.44)^{\star *}\end{array}$ & \\
\hline PosChange & & $\begin{array}{c}0.016 \\
(0.980)\end{array}$ & $\begin{array}{c}0.018 \\
(1.090)\end{array}$ & $\begin{array}{c}0.003 \\
(0.480)\end{array}$ & $\begin{array}{c}0.014 \\
(0.760)\end{array}$ & $\begin{array}{c}0.014 \\
(0.750)\end{array}$ & $\begin{array}{r}0.015 \\
(0.810)\end{array}$ & $\begin{array}{c}0.015 \\
(0.840)\end{array}$ & & $\begin{array}{c}0.004 \\
(0.280)\end{array}$ \\
\hline NegChange & & $\begin{array}{r}0.096 \\
(4.85)^{\star *}\end{array}$ & $\begin{array}{r}0.096 \\
(4.88)^{\star *}\end{array}$ & $\begin{array}{c}0.041 \\
(4.92)^{\star \star}\end{array}$ & $\begin{array}{c}0.078 \\
(3.89)^{\star *}\end{array}$ & $\begin{array}{c}0.083 \\
(3.93)^{\star *}\end{array}$ & $\begin{array}{r}0.087 \\
(4.11)^{\star *}\end{array}$ & $\begin{array}{r}0.087 \\
(4.17)^{\star \star}\end{array}$ & & $\begin{array}{r}0.094 \\
(5.40)^{\star *}\end{array}$ \\
\hline Leader Death & & & $\begin{array}{r}-0.037 \\
(1.410)\end{array}$ & $\begin{array}{c}-0.120 \\
(.)\end{array}$ & & & & & & \\
\hline Tenure & & & & $\begin{array}{c}0.037 \\
(30.51)^{\star *}\end{array}$ & & & & & & \\
\hline Finance & & & & & $\begin{array}{c}0.181 \\
(2.71)^{\star *}\end{array}$ & $\begin{array}{r}0.193 \\
(2.81)^{\star *}\end{array}$ & $\begin{array}{r}0.197 \\
(2.87)^{\star *}\end{array}$ & & & \\
\hline War End & & & & & & $\begin{array}{r}-0.006 \\
(0.300)\end{array}$ & $\begin{array}{r}0.012 \\
(0.460)\end{array}$ & $\begin{array}{r}0.005 \\
(0.210)\end{array}$ & & \\
\hline Civil War & & & & & & & $\begin{array}{r}-0.035 \\
(1.210)\end{array}$ & $\begin{array}{r}-0.027 \\
(0.910)\end{array}$ & & \\
\hline Observations & 1620 & 1620 & 1620 & 1620 & 1382 & 1321 & 1321 & 1382 & 2275 & 2275 \\
\hline Pseudo $R^{\wedge} 2$ & 0.06 & 0.07 & 0.07 & 0.1 & 0.08 & 0.08 & 0.09 & 0.07 & 0.05 & 0.06 \\
\hline
\end{tabular}

Notes: Same as Table 4.1. 
Table 4.4: Robustness to alternative filters

\begin{tabular}{|c|c|c|c|c|c|c|c|c|}
\hline & $\begin{array}{l}\text { Base run } \\
\text { (same as } \\
\text { Table 4.1) }\end{array}$ & $\begin{array}{c}\text { Five-year } \\
\text { horizon }\end{array}$ & $\begin{array}{c}\text { Ten-year } \\
\text { horizon }\end{array}$ & $\begin{array}{l}\text { Difference } \\
=1.5 \mathrm{ppa}\end{array}$ & $\begin{array}{l}\text { Difference } \\
=2.5 \mathrm{ppa}\end{array}$ & $\begin{array}{c}\text { Post-acc. } \\
\text { growth = } \\
3.0 \text { ppa }\end{array}$ & $\begin{array}{c}\text { Post-acc. } \\
\text { growth = } \\
4.0 \mathrm{ppa}\end{array}$ & $\begin{array}{c}\text { WDI data } \\
\text { set }\end{array}$ \\
\hline TOT_thresh90 & $\begin{array}{c}0.0446 \\
(2.62)^{\star \star}\end{array}$ & $\begin{array}{l}-0.016 \\
(0.950)\end{array}$ & $\begin{array}{l}0.029 \\
(2.63)^{\star *}\end{array}$ & $\begin{array}{l}0.040 \\
(2.17)^{*}\end{array}$ & $\begin{array}{l}0.0223 \\
(1.55)\end{array}$ & $\begin{array}{l}0.046 \\
(2.69)^{\star *}\end{array}$ & $\begin{array}{l}0.0387 \\
(2.58)^{\star *}\end{array}$ & $\begin{array}{c}-0.0241 \\
(1.49)\end{array}$ \\
\hline Econ Lib & $\begin{array}{l}0.0217 \\
(1.10)\end{array}$ & $\begin{array}{l}0.048 \\
(2.10)^{*}\end{array}$ & $\begin{array}{l}-0.004 \\
(0.31)\end{array}$ & $\begin{array}{l}0.024 \\
(1.13)\end{array}$ & $\begin{array}{l}0.0109 \\
(0.67)\end{array}$ & $\begin{array}{l}0.029 \\
(1.42)\end{array}$ & $\begin{array}{l}0.0248 \\
(1.42)\end{array}$ & $\begin{array}{c}-0.0208 \\
(0.98)\end{array}$ \\
\hline Poschange & $\begin{array}{l}0.0286 \\
(1.97)^{*}\end{array}$ & $\begin{array}{c}0.000 \\
(0.010)\end{array}$ & $\begin{array}{l}0.077 \\
(6.11)^{\star \star}\end{array}$ & $\begin{array}{l}0.018 \\
(1.16)\end{array}$ & $\begin{array}{l}0.0354 \\
(2.72)^{\star *}\end{array}$ & $\begin{array}{l}0.032 \\
(2.16)^{*}\end{array}$ & $\begin{array}{l}0.0275 \\
(2.05)^{*}\end{array}$ & $\begin{array}{l}0.0393 \\
(2.61)^{* *}\end{array}$ \\
\hline Negchange & $\begin{array}{c}0.108 \\
(5.80)^{\star *}\end{array}$ & $\begin{array}{l}0.081 \\
(4.19)^{\star \star}\end{array}$ & $\begin{array}{c}0.05 \\
(4.03)^{\star \star}\end{array}$ & $\begin{array}{c}0.12 \\
(5.86)^{* *}\end{array}$ & $\begin{array}{l}0.1104 \\
(6.39)^{\star *}\end{array}$ & $\begin{array}{c}0.12 \\
(6.29)^{\star *}\end{array}$ & $\begin{array}{l}0.1067 \\
(6.22)^{\star *}\end{array}$ & $\begin{array}{l}0.0984 \\
(5.19)^{\star *}\end{array}$ \\
\hline $\begin{array}{l}\text { Obs } \\
\text { Pseudo } R^{\wedge} 2\end{array}$ & $\begin{array}{l}2140 \\
0.06\end{array}$ & $\begin{array}{r}2381 \\
0.05\end{array}$ & $\begin{array}{l}1835 \\
0.12\end{array}$ & $\begin{array}{l}2101 \\
0.06\end{array}$ & $\begin{array}{c}2123 \\
0.07\end{array}$ & $\begin{array}{l}2126 \\
0.07\end{array}$ & $\begin{array}{r}2121 \\
0.07\end{array}$ & $\begin{array}{l}1856 \\
0.07\end{array}$ \\
\hline
\end{tabular}

Notes: Same as Table 4.1. 
Table 4.5: Predictability of growth accelerations

\begin{tabular}{lc}
\hline \hline (a) All growth episodes & \\
\hline Proportion of growth accelerations that are preceded or accompanied by: \\
Economic liberalization & $14.5 \%$ \\
Political regime change & $50.6 \%$ \\
External shock & $27.5 \%$ \\
& \\
Proportion of occurrences of column variable that is accompanied or followed by growth accelerations: \\
Economic liberalization & $18.2 \%$ \\
Political regime change & $13.6 \%$ \\
External shock & $5.1 \%$ \\
& \\
(b) Sustained growth episodes only & \\
\hline Proportion of growth accelerations that are preceded or accompanied by: \\
Economic liberalization & $16.2 \%$ \\
Political regime change & $56.8 \%$ \\
External shock & $23.5 \%$ \\
& \\
Proportion of occurrences of column variable that is accompanied or followed by growth accelerations: \\
Economic liberalization & $9.1 \%$ \\
Political regime change & $7.1 \%$ \\
External shock & $1.4 \%$
\end{tabular}

Notes: As in the probits, we allow for a five-year lag between a change in the underlying determinant and a growth acceleration. The timing of the growth acceleration is the three year window centered on the initiation dates shown in Table 2.1. 


\begin{tabular}{|c|c|c|c|c|c|c|}
\hline & \multicolumn{6}{|c|}{ dependent variable } \\
\hline & $\begin{array}{l}\text { All } \\
\text { (1) }\end{array}$ & $\begin{array}{l}\text { All } \\
(2)\end{array}$ & $\begin{array}{l}\text { Sustained } \\
\text { (3) }\end{array}$ & $\begin{array}{l}\text { Sustained } \\
\text { (4) }\end{array}$ & $\begin{array}{l}\text { Sustained } \\
\text { (5) }\end{array}$ & $\begin{array}{c}\text { Unsustained } \\
\text { (6) }\end{array}$ \\
\hline TOT_thresh90 & 0.079 & 0.082 & 0.002 & 0.012 & & 0.019 \\
\hline & $(3.44)^{\star *}$ & $(3.85)^{* *}$ & $(0.23)$ & $(1.20)$ & & $(3.72)^{\star \star}$ \\
\hline Poschange & 0.039 & 0.047 & 0.033 & $\begin{array}{l}0.051 \\
(371)^{* *}\end{array}$ & 0.006 & 0.001 \\
\hline NegChange & 0.123 & 0.120 & 0.038 & 0.039 & 0.042 & 0.021 \\
\hline & $(5.49)^{\star \star}$ & $(5.65)^{\star *}$ & $(2.67)^{\star *}$ & $(2.82)^{\star *}$ & $(2.68)^{\star *}$ & $(4.87)^{\star *}$ \\
\hline Econ Lib & $\begin{array}{l}0.078 \\
(1.87)+\end{array}$ & $\begin{array}{l}0.079 \\
(1.94)+\end{array}$ & & $\begin{array}{l}0.171 \\
(4.14)^{* *}\end{array}$ & $\begin{array}{l}0.112 \\
(4.03)^{\star *}\end{array}$ & \\
\hline Finance & $\begin{array}{l}0.073 \\
(1.49)\end{array}$ & & & & & $\begin{array}{l}0.997 \\
(8.99)^{* *}\end{array}$ \\
\hline obs & 1222 & 1337 & 1034 & 1197 & 1485 & 1164 \\
\hline pseudo $R^{\wedge} 2$ & 0.11 & 0.1 & 0.1 & 0.11 & 0.13 & 0.16 \\
\hline
\end{tabular}

Notes: Same as Table 4.1 